\title{
Prospecting Endophytic Bacterial Colonization and their Potential Plant Growth Promoting Attributes in Hybrid Maize (Zea mays L.)
}

\author{
Premsing Shivsing Marag, Archna Suman* and Shrikant Gond
}

Division of Microbiology, Indian Agricultural Research Institute, New Delhi- 110012, India

*Corresponding author

\begin{tabular}{|l|}
\hline Ke y w or d s \\
Endophytes, PGPB, \\
Growth stages, \\
Hybrid maize
\end{tabular}

A B S T R A C T

Maize, a crop cultivated worldwide, was investigated for colonization endophytic bacteria at different growth stage in different plant parts. Such bacterial interactions have high potential to enhance maize growth and development by means of plant growth promoting activities. 82 morphologically different endophytic bacterial isolates were isolated from hybrid maize variety, Pusa Extra Early Hybrid Maize (PEEHM-5) from root, stem and leaf tissues on different nutrient media at vegetative, flowering and maturity stages of growth. Among growth stages, the maximum population of endophytic bacteria was found at flowering stage followed by vegetative and maturity stage. Among plant tissues, root was harboring higher bacterial population followed by stem and leaf. Upon screening of those 82 endophytic bacterial isolates for plant growth promoting attributes 52 isolates exhibited one or more attributes for plant growth promotion. $\mathrm{P}, \mathrm{K}, \mathrm{Zn}$ solubilization was shown by 17,8 and 21 isolates respectively. 10 isolates tested positive for phytohormone production, whereas 18 isolates were producing siderophore. Few isolates produced ACC deaminase (2), HCN (2) and biological nitrogen fixation (1). Biocontrol activity was shown by 5 isolates against Exerohilum turcicum whereas 3 isolates against Rhizoctonia solani. Primarily 59.6\% isolates were having single PGP trait, $23 \%$ having double, $9.6 \%$ triple and $7.7 \%$ having four PGP traits. Careful selection from the group with multiple characters may lead to development of an effective bioagent.

\section{Introduction}

Various types of microorganisms, including bacteria, fungi and actinomycetes are found inside plants and are designated as endophytes and they live in plant tissues without causing substantive harm to the host. Endophytic bacteria exist within the living tissues of most plant species in form of symbiotic to slightly pathogenic. These have been recovered from a variety of plants including rice, tomato, sweet corn, citrus and potato (Ulrich et al., 2008).
They have significant influence on plant growth and development. The main reason for the interest in endophytes is the realization that if these bacteria can be reintroduced in the endophytic stage, a more stable relationship can be established between beneficial endophytic bacteria and plants, than for rhizospheric or epiphytic bacteria and plants. These constitute a great reservoir of bacterial diversity with a remarkable biotechnological potential (Malfanova et al., 2011). Endophytic bacteria have been implicated in supplying 
biologically fixed nitrogen in non-legumes, and these associations can increase the nitrogen economy of a crop and thus reducing the requirement for nitrogenous fertilizers (Sturz and Nowak, 2000). Bacterial endophytes might intimately interact with cells of the host, taking up secreted metabolites and releasing plant-growthpromoting (PGP) compounds, indole-3-acetic acid (IAA), siderophores and 1aminocyclopropane-1-carboxylic acid (ACC) deaminase production, nitrogen fixation, phosphate solubilization (Hardoim et al., 2011 and Ma et al., 2011), cyanide production (Flaishman et al., 1996) and have capacity to control plant pathogens (Krishnamurthy and Gnanamanickam, 1997). The entry of these endophytic bacteria from rhizosphere is facilitated by passive mode via cracks, wounds and by active mode via hydrolytic enzymes by degradation of the wall for entry. Therefore, endophytes with the plant beneficial traits are potentially excellent plant growth promoters and/or biological control agents for sustainable crop production (Natalia et al., 2011).

Maize (Zea mays L.) is one of the most important grain crop in terms of world production, together with rice and wheat is cultivated in many areas of the world. As world cereal consumption tends to increase due to a constantly growing population, productivity should be significantly improved through different strategies that allow an optimization of yields without implicating an increased sown area (von Braun, 2010). Hybrid varieties of maize are being researched for meeting the crop production targets worldwide and in a scenario of climate change, short duration and resilient varieties of grain crops are being emphasized. To obtain high yields in most crops, as is particularly true in maize, it is necessary to apply huge quantity of mineral fertilizers to the soil (Arruda et al., 2013), that have less than $50 \%$ use efficiency of the applied $\mathrm{N}$ fertilizer by plants (Halvorson et al., 2002). It also contributes to contamination of soils and ground water supplies, leading to health hazards and compromising agricultural sustainability. So there is need to have environmentally friendly and conservative alternatives to protect biodiversity and sustainability of agro ecosystems. Endophytic bacteria are of agronomic interest in particular because they can enhance plant growth by improving nutrition of plants. Therefore, the present study was taken up to decipher such beneficial attributes of endophytic bacteria of hybrid maize.

\section{Materials and Methods}

\section{Experimental site and plant sampling}

Plant samples of hybrid maize variety Pusa Extra Early Hybrid Maize-5 (PEEHM-5) were collected from the farm of Indian Agricultural Research Institute, New Delhi. The samples were collected from the site where uniform growth of healthy plants was seen. Sampling was done at three different stages of plant growth viz. vegetative, flowering and maturity of maize crop. At each sampling event five healthy plants were carefully deep uprooted in a zigzag sampling pattern from the field.

\section{Isolation of maize bacterial endophytes and growth conditions}

Adhering soil particles from the plant samples were removed by several washing of tap followed by sterilized water. Each plant was separated into root, stem and leaf by sterilized scissors. The composite sample from 5 plants was prepared. $10 \mathrm{~g}$ of different tissue samples were sequentially surface sterilized using 70 $\%$ ethanol and sodium hypochlorite $2 \%$ (v/v) for 1 and $3 \mathrm{~min}$, respectively. Surface sterilization was ensured by plating aliquots $(100 \mu \mathrm{l})$ of the final rinse DW onto Trypticase 
Soy Agar (TSA) growth medium plates. The inoculated plates were incubated for $24 \mathrm{hr}$ at $30^{\circ} \mathrm{C}$ to check for any surface microbial contaminant growth. $10 \mathrm{gm}$ of surface sterilized plant material were macerated in a sterilized pestle mortar for $10 \mathrm{~min}$ and were suspended in $90 \mathrm{ml}(0.9 \%)$ saline blank in $250 \mathrm{ml}$ flask to make $10^{-1}$ dilution.

For the exudation or detachment of endophytic bacteria in suspension, samples were shaken on rotary shaker at $30{ }^{\circ} \mathrm{C}$ for $1 \mathrm{hr}$ at 120 revolutions per minute (rpm). Further serially diluted samples $(100 \mu \mathrm{l})$ from different dilutions were spread plated on Nutrient Agar (NA), Trypticase Soy Agar (TSA) plates. Inoculated plates were incubated at $30{ }^{\circ} \mathrm{C}$ for 24-72 hrs.

\section{Selection and purification of different bacterial morphotypes}

Each plate was examined critically and selection of bacterial morphotype was done on the basis of morphological parameters viz. size, shape, colour, margin and texture of bacterial colonies.

All morphotype were purified by quadrant streaking on respective growth medium plates. Purified bacterial morphotypes were preserved both in respective medium slants at $4{ }^{\circ} \mathrm{C}$ as working culture and as $25 \%$ glycerol stock at $-20{ }^{\circ} \mathrm{C}$ for future use.

\section{Functional annotation of endophytic bacteria}

\section{Screening of endophytic bacteria for plant growth promoting traits}

Liquid suspension of the purified bacterial isolates was prepared in respective medium broth to an approximate titre of $10^{6} \mathrm{cfu} / \mathrm{ml}$. The purified isolates were functionally screened for following plant growth promoting attributes:

\section{Phosphate solubilization}

Phosphate solubilizing activity of the isolates was screened on Pikovskaya Agar, (Pikovskaya, 1948). Each plate was divided in sectors and each sector was inoculated with a spot of $10 \mu \mathrm{l}$ bacterial suspension containing $\approx 10^{4}$ bacterial cells. Incubation of the plates was done for $48-96 \mathrm{~h}$ at $30{ }^{\circ} \mathrm{C}$ for the observation of clearing zones which is an indicator of P-solubilization.

\section{Potassium solubilization}

Potassium solubilization by bacterial isolates was screened on modified Aleksandrov agar medium plates (Hu et al., 2006). Each plate was divided in sectors and each sector was inoculated with a spot of $10 \mu \mathrm{l}$ bacterial suspension containing $\approx 10^{4}$ bacterial cells. The plates were incubated at $30{ }^{\circ} \mathrm{C}$ for $48-96 \mathrm{~h}$ for observation of clearing zone which is an indicator of K-solubilization.

\section{Zinc solubilization}

Zinc solubilizing ability was screened on nutrient agar medium plates supplemented with $0.1 \%$ insoluble zinc oxide $(\mathrm{ZnO})$ (Saravanan et al., 2004). Each plate was divided in sectors and each sector was inoculated with a spot of $10 \mu \mathrm{l}$ bacterial suspension containing $\approx 10^{4}$ bacterial cells. The plates were incubated at $30{ }^{\circ} \mathrm{C}$ for $48-96 \mathrm{~h}$ for observation of clearing zone known as an indicator of Zn-solubilization.

\section{Siderophore production}

Isolates were checked for the production of siderophore using specified chrome azurol-S agar medium (CAS blue agar) according to Schwyn and Neilands (1987). The CAS plates were prepared using $100 \mathrm{ml}$ dark blue CAS mixture and nutrient agar medium (300 ml). It was autoclaved separately. The CAS plates 
were inoculated with a spot of $10 \mu \mathrm{l}$ bacterial suspension containing $\approx 10^{4}$ bacterial cells and incubated at $30{ }^{\circ} \mathrm{C}$ for 7-10 days. Development of a deep yellow to orange colour surrounding the colony was a positive indication for siderophore production.

\section{Hydrogen cyanide production}

The production of hydrogen cyanide $(\mathrm{HCN})$ was investigated by inoculating endophytic bacterial isolates in $5 \mathrm{ml}$ nutrient broth containing $4.4 \mathrm{~g} \mathrm{~L}^{-1}$ glycine in $30 \mathrm{ml}$ glass tubes. A strip of sterilized filter paper saturated with solution of picric acid $(0.5 \%)$ and sodium carbonate (2\%) was placed in cotton plug sealed tubes containing different bacterial isolates and incubated for 7-15 days at $30{ }^{\circ} \mathrm{C}$. The change of filter paper colour from yellow to light brown or reddish brown was positive indication for the production of HCN (Bakker and Schippers 1987).

\section{1-Aminocyclopropane-1-carboxylate deaminase production}

ACC deaminase activity was checked by their ability to utilize 1-Aminocyclopropane -1carboxylate (ACC) as sole source of nitrogen as given by Jacobson et al., 1994. MDF (modified Dworkin and Foster medium) agar plates were used for checking ACC deaminase activity. MDF agar plates supplemented with $0.3 \mathrm{~g}$ of $\mathrm{ACC} \mathrm{\textrm {L } ^ { - 1 }}$ were inoculated with a spot of $10 \mu \mathrm{l}$ bacterial suspension containing $\approx 10^{4}$ bacterial cells. Bacterial isolates was also spotted on plates of MDF medium containing $0.3 \mathrm{~g} \mathrm{~L} \mathrm{~L}^{-1}$ ammonium sulphate as positive control and on plain MDF agar plate as negative control. Incubated plates for $72 \mathrm{~h}$ at $30{ }^{\circ} \mathrm{C}$ were observed for the growth.

\section{Indole acetic acid}

The qualitative analysis for production of IAA was carried out according to Bric et al.,
(1991). For IAA production, $10 \mu \mathrm{l}$ bacterial suspension containing $\approx 10^{4}$ bacterial cells was spotted on Luria agar plates supplemented with $50 \mu \mathrm{g} \mathrm{mL}^{-1}$ tryptophan. Above mentioned plates were dried at ambient temperature and were covered with paper disc of sterile Whatman No. 1 filter.

The plates were incubated at $30{ }^{0} \mathrm{C}$ for $24 \mathrm{~h}$. The filter paper disc removed was treated with Salkowski solution. The development of pink colour was an indication of IAA production.

\section{Acetylene Reduction Ability (ARA)}

Bacterial isolates were screened for ARA activity on $\mathrm{N}$-free Jensen medium for isolates using gas chromatograph according to Hardy et al., (1973).

\section{Biocontrol activities against potential maize pathogens}

Biocontrol activity of the isolated endophytic bacteria was assayed using dual inoculation technique against two maize pathogens, Exserohilum turcicum (Turcicum leaf blight) and Rhizoctonia solani (root and stalk rot) according to the method described by Sijam and Dikin (2005).

These test fungi were grown separately on potato dextrose agar medium and its $3 \mathrm{~mm}$ disc was placed in the center of each modified PDA plates (PDA:NA:1:1). After incubation of $6 \mathrm{~h}$ at $37{ }^{\circ} \mathrm{C}$ the same plates were inoculated with a spot of $10 \mu \mathrm{l}$ bacterial suspension containing $\approx 10^{4}$ bacterial cells and the plates were incubated for 5-7 days at 30 ${ }^{\circ} \mathrm{C}$. Plates inoculated with fungal disc alone were used as a control.

Three replications were maintained for each isolate. The zone of inhibition by bacteria against fungal pathogen was observed after sufficient incubation period. 


\section{Results and Discussion}

\section{Isolation of maize bacterial endophytes}

Maize plant parts at various growth stages housed variable counts of culturable bacterial endophytes. It varied from $7.2 \times 10^{3}$ to $1.9 \times 10^{4}$ cfu $\mathrm{g}^{-1}$ of plant tissue. The maximum counts were observed in flowering stage in all three tissues viz. root, stem and leaf. Amongst tissues the maximum counts were observed in roots at three growth stages viz. vegetative, flowering and maturity (Table 1). On the basis of morphological characters 82 diverse isolates were purified of which 20 morphotypes were from vegetative, 30 from flowering and 32 from maturity stage across different tissues (Table 1).

\section{Qualitative screening for plant growth promoting attributes}

\section{Phosphate solubilization ability}

All purified bacterial endophytic isolates were screened in vitro for P-solubilizing activity by spotting on Pikovskaya Agar medium plates. A clearing zone around the colony is an indication of P-solubilization (Fig. 1). A total of 17 isolates from PEEHM-5 were found to possess P- solubilization activity (Table 2), out of which 3 isolates belonged to vegetative stage, 10 to flowering and 4 to maturity stage (Fig. 2) and further it was found that across different growth stages there were 8 isolates from root, 5 from stem and 4 from leaves as $\mathrm{P}$ solubiliser. Verma et al., (2015) has reported the phosphate solubilizing property of endophytic bacteria viz. Azotobacter, Burkholderia, Citrobacter, Enterobacter, Pantoea and Pseudomonas in wheat. There are reports of bacteria belonging to genera Bacillus, Pseudomonas, Serratia, Enterobacter, solubilizing the insoluble phosphate compounds and aid in plant growth (Hameeda et al., 2008). Joe et al., (2016) reported two salt tolerant endophytic and phosphate solubilizing bacteria ACMS25 and PVMX4 isolated from Phyllanthus amarus and got identified them based on 16s rRNA sequencing as Acinetobacter sp. and Bacillus sp.

\section{Potassium solubilization}

All purified bacterial endophytic isolates were screened in vitro for $\mathrm{K}$ - solubilizing activity by spotting on Petri plates containing modified Aleksandrov agar medium. A clearing zone around the colony is an indication of $\mathrm{K}$ solubilizers (Fig. 1). A total of 8 isolates from PEEHM-5 were found to possess Ksolubilization activity (Table 2), out of which 7 isolates from vegetative and only 1 from flowering stage were K- solubilizer (Fig. 2) and across different stage 7 were from root and 1 from stem respectively. Yuan et al., (2015) had done PGP characterization and the $16 \mathrm{~S}$ rDNA sequence analysis of endophytic bacteria isolated from the root, rhizome, stem, and leaves of Moso Bamboo and showed that the 20 phosphorus- and potassium-solubilizing bacteria belong to 14 species from 10 genera, and mainly consist of Alcaligenes spp., Enterobacter spp. and Bacillus spp. The potential endophytic bacteria solubilizing $\mathrm{K}$ from seedling roots of date palm (Phoenix dactylifera L.) were Bacillus endophyticus strain 2DT, Acinetobacter pittii, Achromobacter sp. (Yaish et al., 2015).

\section{Zinc solubilization}

All purified bacterial endophytic isolates were screened in vitro for $\mathrm{Zn}$ - solubilizing activity by spotting these on nutrient agar medium plates supplemented with $0.1 \%$ insoluble zinc compounds as $(\mathrm{ZnO})$. A clearing zone around the colony is an indication of $\mathrm{Zn}$-solubilizers (Fig. 1). A total of 21 isolates (Nearly $25 \%$ of total isolates) PEEHM-5 were found to possess Zn- solubilizing activity. Among 21 
Zn- solubilizing isolates of PEEHM-5 (Table 2), 3 were from vegetative, 9 from flowering and 9 from maturity stage (Fig. 2) respectively and across different stage 11 isolates were from root, 6 from stem and 4 from leaves respectively. Yaish et al., (2015) reported potential zinc solubilizing endophytic bacteria from seedling roots of date palm (Phoenix dactylifera L.) belonging to various genera of Achromobacter, Acinetobacter, Bacillus, Chryseobacterium, Enterobacter, Klebsiella, Paenibacillus, Rhodococcus and Staphylococcus.

\section{Siderophore production}

All purified bacterial endophytic isolates were screened in vitro for siderophore production. Overall 18 isolates from PEEHM-5 were found to possess siderophore production ability (Fig. 1 and Table 2). A single isolate from vegetative, 11 from flowering and 6 from maturity stage (Fig. 3) were found to produce siderophore respectively and out of these 8 isolates were from root, 6 from stem and 4 from leaves respectively across different stage. Hydroxamate-type Siderophore producing endophytic bacteria Methylobacterium spp., has been reported from citrus plants (Lacava et al., 2008).

\section{Hydrogen cyanide production}

All purified bacterial endophytic isolates were screened in vitro for hydrogen cyanide production. Only 2 isolates from PEEHM-5 were found to possess hydrogen cyanide production ability (Fig. 1 and Table 2). Among 2 isolates, a single isolate each from vegetative and flowering stage was hydrogen cyanide producer (Fig. 3) and across different stage 1 was from root and another one was from leaves respectively. Rodrigues et al., (2016) reported isolation of 136 endophytic bacteria associated with sugarcane with 83 of them presenting some plant growth mechanism: $47 \%$ phosphate solubilizers, 26 $\%$ nitrogen fixers and $57 \%$ producing IAA, $0.7 \% \mathrm{HCN}$ and chitinase, $45 \%$ ammonia, 30 $\%$ cellulose and $8 \%$ pectinase. The seven best isolates were tested for their ability to promote plant growth in maize. The isolates tested for plant growth promotion belong to the Enterobacteriaceae family and the Klebsiella, Enterobacter and Pantoea genera.

\section{1-Aminocyclopropane-1-carboxylate deaminase production}

All purified bacterial endophytic isolates were screened in vitro for ACC utilizing ability as sole source of nitrogen. 2 isolates from PEEHM-5 were found to possess ACC utilizing ability (Fig. 1 and Table 2). In case of PEEHM-5, a single isolate each from flowering and maturity (Fig. 3) and across different stage one was from stem and other one from leaves as ACC utilizing isolate. ACC deaminase producing bacteria helps plant to relieve stress caused by ethylene by breaking down ACC into ammonia and a-ketobutyrate (Mayak et al., 1999).

Table.1 Isolation of total endophytic bacteria $\left(\mathrm{cfu} \mathrm{g}^{-1}\right) *$ from different growth stages and tissues

\begin{tabular}{|l|l|l|l|}
\hline Growth stages/ tissues & Root & Stem & Leaf \\
\hline Vegetative & $\mathbf{1 . 6 X 1 0}^{4}(\mathbf{7})$ & $\mathbf{1 . 0 X 1 0}^{\mathbf{4}}(\mathbf{8})$ & $\mathbf{8 . 8 X 1 0 ^ { 3 }}(\mathbf{5})$ \\
\hline Flowering & $\mathbf{1 . 9 X 1 0}^{4}(\mathbf{1 6})$ & $\mathbf{1 . 5 X 1 0}^{\mathbf{4}}(\mathbf{4})$ & $\mathbf{1 . 3 X 1 0}^{\mathbf{4}}(\mathbf{1 0})$ \\
\hline Maturity & $\mathbf{1 . 2 X 1 0}^{\mathbf{4}}(\mathbf{7})$ & $\mathbf{8 . 1 X 1 0}^{\mathbf{3}}(\mathbf{1 1})$ & $\mathbf{7 . 2 X 1 0 ^ { 3 } ( 1 4 )}$ \\
\hline
\end{tabular}

Figure in parenthesis indicate number of purified morphotypes 
Table.2 Plant growth promoting activities of endophytic bacteria from PEEHM-5

\begin{tabular}{|c|c|c|c|c|c|c|c|c|c|c|c|}
\hline \multirow[t]{2}{*}{ Isolates } & \multicolumn{3}{|c|}{ Solubilization } & \multicolumn{4}{|c|}{ Production } & \multirow[b]{2}{*}{ 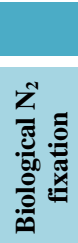 } & \multicolumn{3}{|c|}{ Biocontrol } \\
\hline & 0 & 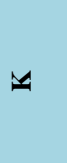 & 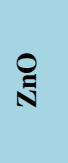 & $\frac{0}{\frac{0}{0}}$ & Z & $\underset{u}{u}$ & 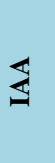 & & 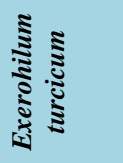 & 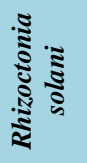 & \\
\hline PHM5-1 & - & + & - & - & - & - & - & - & - & & - \\
\hline PHM5-2 & - & + & - & - & - & - & - & - & - & & + \\
\hline PHM5-3 & - & - & - & - & + & - & - & - & + & & - \\
\hline PHM5-5 & - & + & - & - & - & - & - & - & - & & - \\
\hline PHM5-6 & - & + & + & - & - & - & - & - & - & & - \\
\hline PHM5-7 & - & + & - & - & - & - & - & - & - & & - \\
\hline PHM5-8 & - & + & + & - & - & - & - & - & - & & - \\
\hline PHM5-10 & - & - & - & + & - & - & - & - & - & & - \\
\hline PHM5-11 & - & - & + & - & - & - & - & - & - & & - \\
\hline PHM5-12 & + & - & - & - & - & - & - & - & - & & - \\
\hline PHM5-13 & + & - & - & - & - & - & - & - & - & & - \\
\hline PHM5-17 & + & - & - & - & - & - & - & - & - & & - \\
\hline PHM5-21 & + & - & - & - & - & - & - & - & - & & - \\
\hline PHM5-22 & - & - & - & + & - & - & - & - & - & & - \\
\hline PHM5-23 & + & - & - & - & - & - & - & - & - & & - \\
\hline PHM5-24 & - & - & + & + & - & - & - & - & - & & - \\
\hline PHM5-25 & - & - & - & + & - & - & - & - & + & & + \\
\hline PHM5-26 & - & - & + & - & - & - & - & - & - & & - \\
\hline PHM5-27 & - & - & + & - & - & - & - & - & - & & - \\
\hline PHM5-28 & - & - & + & - & - & - & - & - & - & & - \\
\hline PHM5-30 & + & - & + & + & - & - & + & - & - & & - \\
\hline PHM5-31 & - & - & + & + & - & - & - & - & - & & - \\
\hline PHM5-32 & + & - & - & - & - & - & + & - & - & & - \\
\hline PHM5-33 & + & - & - & - & - & - & - & - & + & & + \\
\hline PHM5-35 & + & - & - & - & - & - & - & - & - & & - \\
\hline PHM5-36 & - & - & + & + & - & - & - & - & - & & - \\
\hline PHM5-37 & + & - & - & + & - & - & + & + & - & & - \\
\hline PHM5-38 & + & - & - & + & - & + & + & - & - & & - \\
\hline PHM5-39 & + & - & - & - & - & - & + & - & - & & - \\
\hline PHM5-40 & - & - & + & - & - & - & - & - & - & & - \\
\hline PHM5-44 & - & + & - & + & - & - & - & - & - & & - \\
\hline PHM5-46 & + & - & - & - & + & - & - & - & - & & - \\
\hline PHM5-48 & - & - & - & + & - & - & - & - & - & & - \\
\hline PHM5-49 & - & - & + & - & - & - & - & - & - & & - \\
\hline PHM5-50 & - & - & + & - & - & - & - & - & - & & - \\
\hline PHM5-54 & - & - & + & - & - & - & - & - & - & & - \\
\hline PHM5-55 & + & - & - & + & - & - & + & - & - & & - \\
\hline PHM5-56 & + & - & - & - & - & - & - & - & + & & - \\
\hline PHM5-58 & - & - & + & - & - & - & - & - & - & & - \\
\hline PHM5-59 & - & - & - & + & - & - & - & - & - & & - \\
\hline PHM5-61 & - & - & + & - & - & - & - & - & - & & - \\
\hline PHM5-63 & - & - & - & + & - & - & - & - & & & - \\
\hline PHM5-65 & - & - & + & - & - & - & + & - & + & & - \\
\hline PHM5-67 & - & - & - & + & - & - & - & - & - & & - \\
\hline PHM5-68 & - & - & - & + & - & - & - & - & - & & - \\
\hline PHM5-69 & - & - & + & - & - & - & - & - & - & & - \\
\hline PHM5-70 & - & - & - & + & - & - & - & - & - & & - \\
\hline PHM5-72 & - & - & - & - & - & + & - & - & - & & - \\
\hline PHM5-73 & + & - & + & - & - & - & + & - & - & & - \\
\hline PHM5-74 & - & - & + & - & - & - & + & - & - & & - \\
\hline PHM5-76 & + & + & + & + & - & - & - & - & - & & - \\
\hline PHM5-80 & - & - & - & - & - & - & + & - & - & & - \\
\hline
\end{tabular}


Fig.1 Plant growth promoting traits; Solubilization of phosphorus, potassium and zinc; HCN, siderophore and ACC; biocontrol against Rhizoctonia solani

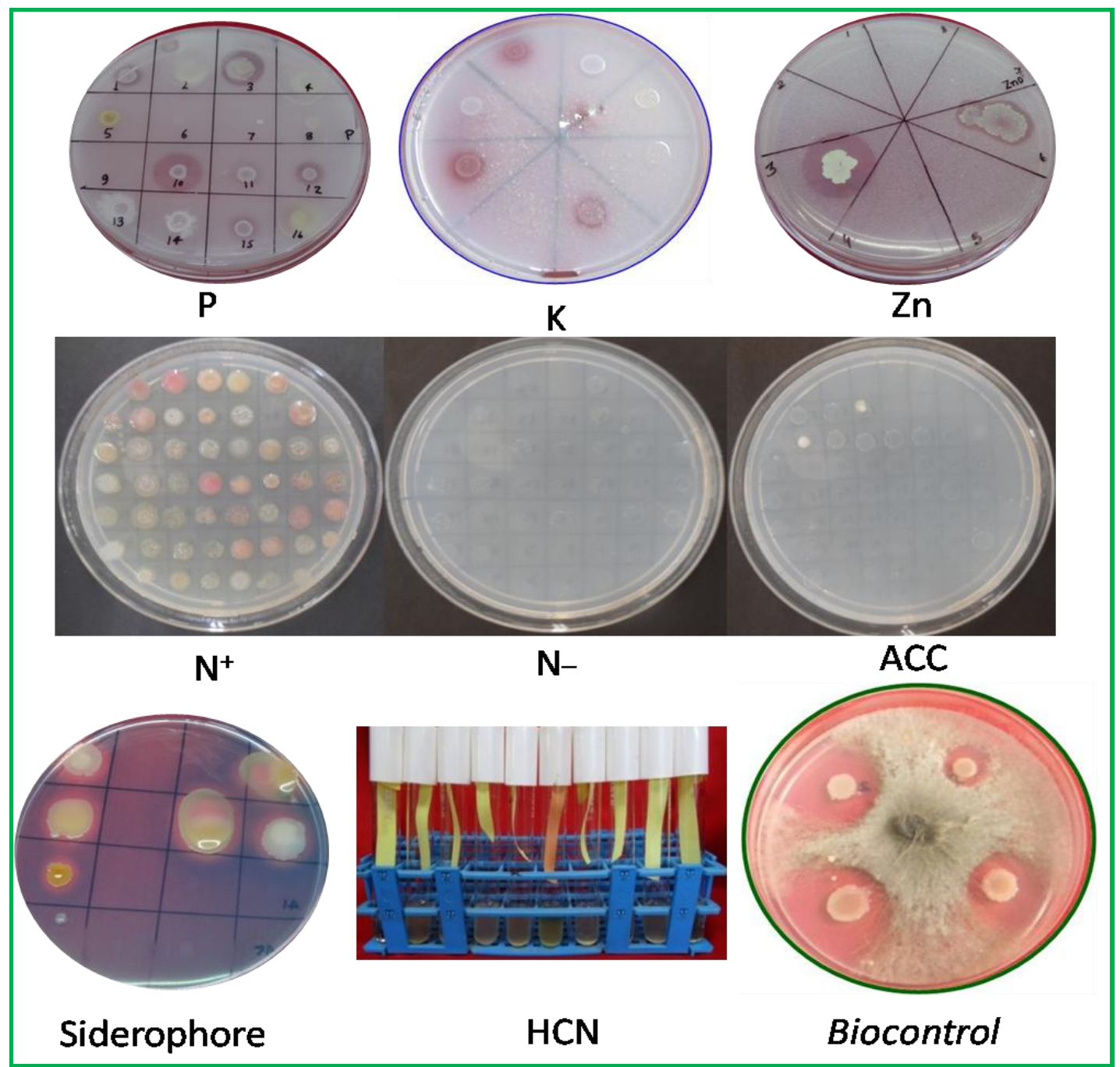

Fig.2 Nutrient solubilization by endophytic bacteria from PEEHM-5

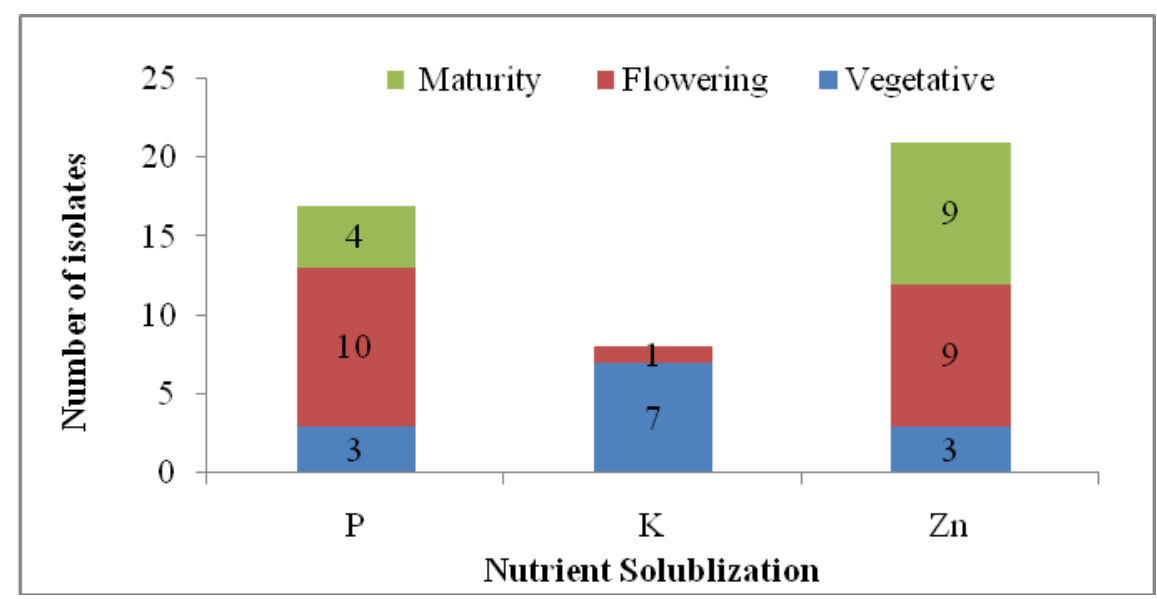


Fig.3 Production of compounds by endophytic bacteria from PEEHM-5

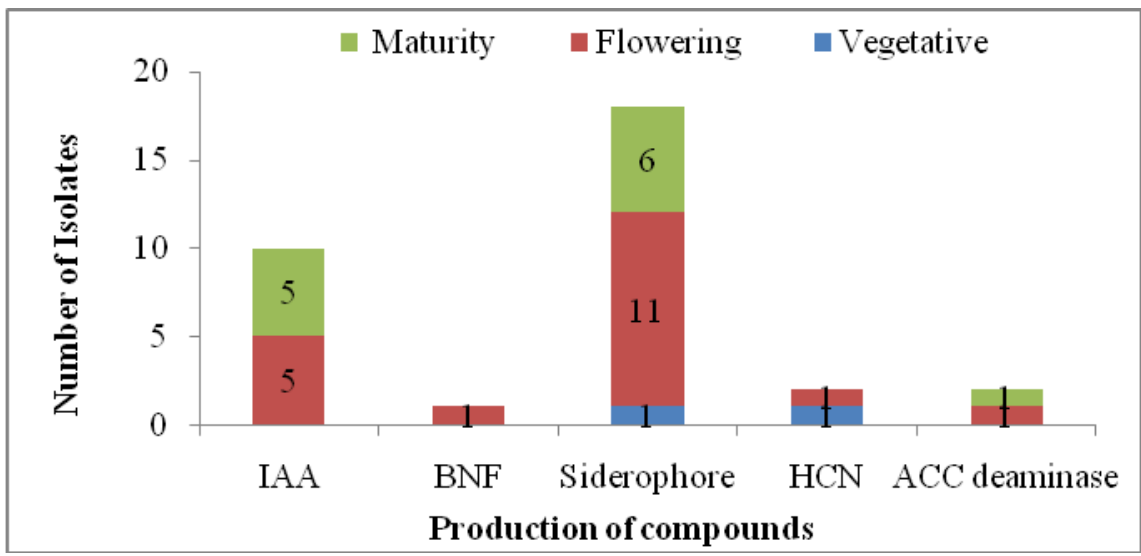

Fig.4 Biocontrol activity against fungal pathogens of endophytic bacteria from PEEHM-5

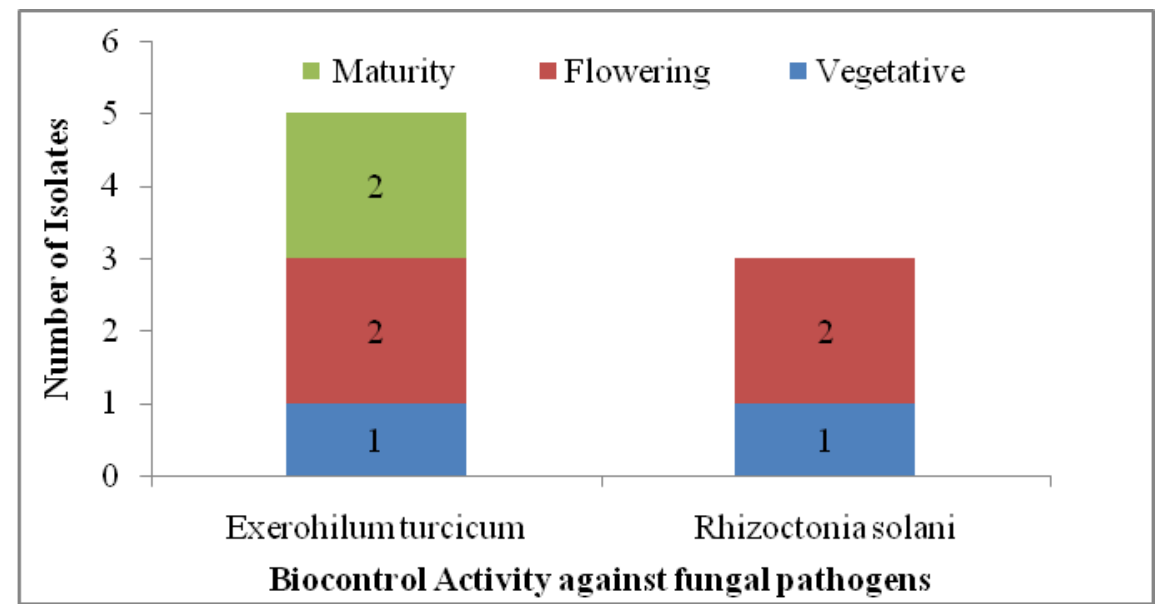

$\mathrm{Xu}$ et al., (2014), reported that endophytic bacteria Bacillus subtilis (HYT-12-1) isolated from tomato seeds had PGP traits along with ACC deaminase activity (112.02 nmol $\alpha$ ketobutyrate $\mathrm{mg}^{-1}$ protein $\mathrm{h}^{-1}$ ). Verma et al., (2014) also reported psychrotolerant and drought tolerant endophytic bacteria from wheat producing ACC deaminase by various genera viz. Arthrobacter, Flavobacterium, Bacillus, Pseudomonas, Methylobacterium and Enterobacter.

\section{Indole acetic acid production}

All purified bacterial endophytic isolates were screened in vitro for Indole acetic acid production. A total of 10 isolates from
PEEHM-5 were found to possess Indole acetic acid production ability (Table 2). Among 10 isolates, 5 from flowering and 5 from maturity stage (Fig. 3) while across different stage 3 were from root, 4 from stem and 2 from leaves respectively were IAA producer. Szilagyi-Zecchin et al., (2014) reported six endophytic bacteria of corn roots which were identified by sequencing of the 16S rRNA gene as Bacillus sp. and as Enterobacter sp. Four of the strains, CNPSo 2476, CNPSo 2477, CNPSo 2478 and CNPSo 2480 were shown to have nitrogen fixation ability evaluated through the acetylene reduction assay and amplification of nifH gene. Two Bacillus strains (CNPSo 2477 and CNPSo 2478) found to possess outstanding 
skills for the production of IAA, siderophore.

\section{Acetylene reduction activity (ARA)}

PMH5-37 was the single isolate from PEEHM-5 isolated at vegetative stage from stem and had nitrogenase activity (Table 2). Ji et al., (2014) reported diazotrophic endophytic bacteria from the leaves, stems, and roots of 10 rice cultivars belonging to various genera viz. Penibacillus, Microbacterium, Bacillus and Klebsiella. Suman et al., (2005) screened seven Gluconacetobacter diazotrophicus strains isolated from sugarcane roots for their efficiency to promote growth and nutrient uptake in sugarcane at three levels of urea $\mathrm{N}$ $\left(0,75\right.$, and $\left.150 \mathrm{~kg} \mathrm{~N} \mathrm{ha}{ }^{-1}\right)$. Following inoculation by these strains improvement in germination, tiller number and plant height was observed.

\section{Biocontrol activities against potential maize pathogens}

All purified bacterial endophytic isolates were screened in vitro for biocontrol activity against two maize pathogens Exserohilum turcicum (Turcicum leaf blight) and Rhizoctonia solani (root and stalk rot). The zone of inhibition by bacteria against fungal pathogen was observed after sufficient incubation period. 5 isolates from PEEHM-5 were found to possess antagonistic activity against Exserohilum turcicum (Table 1). A single isolate was antagonistic against Exserohilum turcicum from vegetative, 2 from flowering and 2 from maturity stages (Fig. 4) respectively of which 4 were from root and only 1 from stem respectively across different stage. Three isolates from PEEHM5 , were found to possess antagonistic activity against Rhizoctonia solani (Table 1). A single isolate from vegetative stage and 2 isolates from flowering stage were antagonistic against Rhizoctonia solani (Fig. 4) of which all the three were from root across different stage. White et al., (2014) reported the antifungal activity of $B$. amyloliquefaciens an endophyte from vanilla orchids which gave protection to plant seedlings from pathogens. Verma et al., (2015) reported that many species of genera Bacillus, Exiguobacterium, Micrococcus, Pseudomonas and Psychrobacter showe antagonistic properties against fungal pathogens Fusarium graminerum, Rhizoctonia solani and Macrophomina phaseoli.

The present study provides baseline information on effect of plant developmental stage on differential colonization of culturable endophytic bacterial diversity in different plant tissue and their plant probiotics functions in a hybrid maize variety. Primarily $59.6 \%$ isolates were having single PGP trait, $23 \%$ having double, $9.6 \%$ triple and $7.7 \%$ having four PGP traits. Multi-PGP trait isolates selected in this study need to be further investigated under pot and field conditions for commercialization among farmers for enhancing maize growth and productivity.

\section{Acknowledgements}

Authors thank Post Graduate School and Director, ICAR-IARI for providing JRF during M.Sc. program of the first author. We thank Dr R.N Gadag, Division of Genetics, IARI, for his assistance in providing maize samples.

\section{References}

Arruda, L., Beneduzi, A., Martins, A., Lisboa, B., Lopes, C., Bertolo, F., Passaglia, L.M.P. and Vargas, L.K. 2013. Screening of rhizobacteria isolated from maize (Zea mays L.) in Rio Grande do Sul State (South Brazil) and analysis of 
their potential to improve plant growth. Applied Soil Ecology. 63:15-22.

Bakker, A.W. and Schippers, B.1987. Microbial cyanide production in the rhizosphere in relation to potato yield reduction and Pseudomonas spp. mediated plant growth stimulation. Soil Biol. Biochem., 19: 451-457.

Bric, J.M., Bostock, R.M. and Silverstone, S.E.1991. Rapid in situ assay for indole acetic acid production by bacteria immobilized on a nitrocellulose membrane. Appl. Environ. Microbiol., 57:535-538.

Flaishman, M.A., Eyal, Z., Zilberstein, A., Voisard, C. and Haas, D.1996.Suppression of Septoria tritici blotch and leaf rust of wheat by recombinant cyanide-producing strains of Pseudomonas putida. MPMIMolecular Plant Microbe Interactions., 9: 642-645.

Halvorson, A.D., Peterson, G.A. and Reule, C.A.2002. Tillage system and crop rotation effects on dry land crop yields and soil carbon in the Central Great Plains. Agron. J., 94:1429-1436.

Hameeda, B., Harini, G., Rupela, O.P., Wani, S.P. and Reddy, G. 2008. Growth promotion of maize by phosphatesolubilizing bacteria isolated from composts and macrofauna. Microbiol. Res., 163:234-42.

Hardoim, P.R., Andreote, F.D., ReinholdHurek, B., Sessitsch, A., van Overbeek, L.S. and Elsas, V.J.D. 2011. Rice root associated bacteria: insights into community structures across 10 cultivars. FEMS Microbial Ecol. 77:154-164.

Hardy, R.W.F., Burns, R.C. and Holsten, R.D.1973. Applications of the acetylene ethylene assay for measurement of nitrogen fixation. Soil Biol. Biochem., 5:47-81.
Hu, X., Chen, J. and Guo, J.2006. Two phosphate- and potassium-solubilizing bacteria isolated from Tianmu Mountain, Zhejiang, China. World J. Microbiol. Biotechnol., 22(9):983-990.

Von Braun, J., (2010). "The world food situation. New driving forces and required actions," World Food Situation New Driving Forces and Required Action Released by the International Food Policy Institute.

Jacobson, C.B., Pasternak, J. and Glick, B.R.1994. Partial purification and characterization of 1aminocyclopropane-1-carboxylate deaminase from the plant growth promoting rhizobacterium Pseudomonas putida GR12-2. Can. J. Microbiol., 40:1019-1025.

Ji, S.H., Gururani, M.A. and Chun, S.C. 2014. Isolation and characterization of plant growth promoting endophytic diazotrophic bacteria from Korean rice cultivars. Microbiol. Resear., 169(1):83-98.

Joe, M. M., Devaraj, S., Benson, A. and Sa, T. 2016. Isolation of phosphate solubilizing endophytic bacteria from Phyllanthus amarus Schum \& Thonn: Evaluation of plant growth promotion and antioxidant activity under salt stress. Journal of Applied Research on Medicinal and Aromatic Plants, 3(2): 71-77.

Krishnamurthy, K. and Gnanamanickam, S.S.1997. Biological control of sheath blight of rice: induction of systemic resistance in rice by plant-associated Pseudomonas spp. Curr Sci., 72: 331334.

Lacava, P.T., Silva-Stenico, M.E., Araújo, W.L., Simionato, A.V.C., Carrilho, E., Tsai, S.M. and Azevedo, J.L., 2008. Detection of siderophores in endophytic bacteria Methylobacterium spp. associated with Xylella fastidiosa subsp. 
pauca. Pesquisa Agropecuária Brasileira., 43(4): 521-528.

Lucy, M., Reed, E. and Glick, B.R. 2004. Application of free living plant growth promoting rhizobacteria. Antonie Van Leeuw., 86:1-25.

Ma, Y., Prasad, M., Rajkumar,M. and Freitas, H. 2011. Plant growth promoting rhizobacteria and endophytes accelerate phytoremediation of metalliferous soils. Biotechnol.Advan., 29:248-258.

Malfanova, N., Kamilova, F., Validov, S., Shcherbakov, A., Chebotar, V., Tikhonovich, I. and Lugtenberg, B. 2011. Characterization of Bacillus subtilis HC8, a novel plant- beneficial endophytic strain from giant hogweed. Microbi. biotechnol., 4:523-532.

Mayak, S., Tirosh, T. and Glick, B.R.1999. Effect of wild-type and mutant plant growth promoting rhizobacteria on the rooting of mung bean cuttings. J. Plant Growth Regul., 18(2):49-53.

Natalia, M., Faina, K., Shamil, V., Andrey, S., Vladimir, C., Igor, T., and Ben, L.2011. Characterization of Bacillus subtilis HC8, a novel plant-beneficial endophytic strain from giant hogweed. Microb. Biotech., 4(4): 523-532.

Pikovskaya, R.1948. Mobilization of phosphorus in soil in connection with vital activity of some microbial species. Microbiologiya., 17: 362-370.

Rodrigues, A.A., Forzani, M.V., Soares, R.D.S., Sibov, S.T. and Vieira, J.D.G. 2016. Isolation and selection of plant growth-promoting bacteria associated with sugarcane. Pesquisa Agropecuária Tropical., 46(2):149-158.

Saravanan, V.S., Madhaiyan, M. and Thangaraju, M.2007. Solubilization of zinc compounds by the diazotrophic, plant growth promoting bacterium Gluconacetobacter diazotrophicus. Chemosphere., 66(9): 1794-1798
Schwyn, B. and Neilands, J.B.1987. Universal chemical assay for the detection and determination of siderophores. Anal. Biochem., 160: 47-56.

Sijam, K. and Dikin, A.2005. Biochemical and physiological characterization of Burkholderia cepacia as biocontrol agent. Int. J. Agri. Biol., 7(3):385-388.

Sturz, A.V., Christie, B.R. and Nowak, J. 2000. Bacterial endophytes: potential role in developing sustainable systems of crop production. Crit. Rev. Plant Sci., 19: 1-30.

Suman, A., Gaur, A., Shrivastava, A.K. and Yadav, R.L. 2005. Improving sugarcane growth and nutrient uptake by inoculating Gluconacetobacter diazotrophicus. Plant Growth Regula., 47(2-3):155-162.

Szilagyi-Zecchin, V.J., Ikeda, A.C., Hungria, M., Adamoski, D., Kava-Cordeiro, V., Glienke, C. and Galli-Terasawa, L.V. 2014. Identification and characterization of endophytic bacteria from corn (Zea mays L.) roots with biotechnological potential in agriculture. $A M B$ Express., $4(1): .26$.

Ulrich, K., Ulrich, A. and Ewald, D. 2008. Diversity of endophytic bacterial communities in poplar grown under field conditions. FEMS microbiology ecology., 63 (2):169-180.

Verma, P., Yadav, A.N., Khannam, K.S., Panjiar, N., Kumar, S., Saxena, A.K. and Suman, A. 2015. Assessment of genetic diversity and plant growth promoting attributes of psychrotolerant bacteria allied with wheat (Triticum aestivum) from the northern hills zone of India. Ann. Microbiol., 65: 18851899.

Verma, P., Yadav, A.N., Kazy, S.K., Saxena, A.K. and Suman, A. 2014. Evaluating the diversity and phylogeny of plant growth promoting bacteria associated with wheat (Triticum aestivum) growing 
in central zone of India. Int. J. Curr. Microbiol. Appl. Sci., 3(5):432-447.

White, J.F., Torres, M.S., Sullivan, R.F., Jabbour, R.E., Chen, Q., Tadych, M., Belanger, F.C. 2014. Occurrence of Bacillus amyloliquefaciens as a systemic endophyte of vanilla orchids. Microscopy Res. Tech., 77(11): 874885.

Xu, M., Sheng, J., Chen, L., Men, Y., Gan, L., Guo, S. and Shen, L. 2014. Bacterial community compositions of tomato (Lycopersicum esculentum Mill.) seeds and plant growth promoting activity of ACC deaminase producing Bacillus subtilis (HYT-12-1) on tomato seedlings. World J. Microbiol. Biotechnol., 30(3): 835-845.

Yaish, M.W., Antony, I. and Glick, B.R. 2015. Isolation and characterization of endophytic plant growth-promoting bacteria from date palm tree (Phoenix dactylifera L.) and their potential role in salinity tolerance. Antonie Van Leeuw., 107(6): 1519-1532.

Yuan, Z.S., Liu, F. and Zhang, G.F. 2015. Characteristics and biodiversity of endophytic phosphorus-and potassiumsolubilizing bacteria in Moso Bamboo (Phyllostachys edulis). Acta Biologica Hungarica., 66(4):449-459.

\section{How to cite this article:}

Premsing Shivsing Marag, Archna Suman and Shrikant Gond. 2018. Prospecting Endophytic Bacterial Colonization and their Potential Plant Growth Promoting Attributes in Hybrid Maize (Zea mays L.). Int.J.Curr.Microbiol.App.Sci. 7(03): 1292-1304.

doi: https://doi.org/10.20546/ijcmas.2018.703.154 